\title{
Frequency of musculoskeletal pain and thermal comfort in students of dentistry
}

\author{
Bruna Katarine Bezerra Paz ${ }^{1}$, Vandilson Pinheiro Rodrigues ${ }^{2}$, Maryangela Godinho Pereira Bena ${ }^{3}$, \\ Débora Bevilaqua Grossi ${ }^{4}$, Lidiane Lima Florêncio ${ }^{5}$, Patricia Maria Wiziack Zago ${ }^{6}$ \\ and Maria Claudia Gonçalves ${ }^{7}$
}

\author{
${ }^{1}$ Universidade CEUMA - UniCEUMA, São Luís-Maranhão, Brasil \\ bkpaz@hotmail.com \\ ${ }^{2}$ Universidade Federal do Maranhão, São Luís-Maranhão, Brasil \\ vandilson@hotmail.com \\ ${ }^{3}$ Universidade CEUMA - UniCEUMA, São Luís-Maranhão, Brasil \\ maryangelapereira@hotmail.com.br \\ ${ }^{4}$ Universidade de São Paulo (FMRP-USP), Ribeirão Preto, São Paulo, Brasil \\ deborabg@fmrp.usp.br \\ ${ }^{5}$ Universidad Rey Juan Carlos, Madrid, Spain \\ lidianelimaflorencio@gmail.com \\ ${ }^{6}$ Universidade CEUMA - UniCEUMA, São Luís-Maranhão, Brasil \\ patizago@hotmail.com \\ ${ }^{7}$ Universidade CEUMA - UniCEUMA, São Luís-Maranhão, Brasil \\ mcgfisio0@gmail.com
}

\begin{abstract}
The objective of this study was to evaluate the frequency of musculoskeletal symptoms (MS) and thermal sensation in the clinical setting in dental students. We evaluated 124 students in the curricular stage. The frequency of MS was evaluated with the Nordic Musculoskeletal Questionnaire and the thermal sensation through reporting by scale ranging from very cold to very hot. About $80 \%$ of the students had some MS. The sites with the highest frequency were the regions of the thoracic spine (46\%) and neck (45\%) $(P<0.001)$. Neck pain was associated with thermal discomfort $(P=0.02)$, especially in women. Positive correlations were also observed between the different anatomical regions and intensity of the symptoms $(P<0.05)$, mainly between the thoracic and lumbar spine $(R s$ $=0.53)$, knee and ankle/foot $(R s=0.52)$, and neck and shoulder $(R s=0.51)$ for both sexes. Regarding thermal sensation of the clinical environment, the clinical environment temperature was considered comfortable by $33.9 \%$ of the patients. MS are frequent in dentistry students, especially in the spinal region, and pain in the neck region is correlated with thermal sensation of cold, calling attention to the need for the prevention and for ergonomic and lifestyle changes.
\end{abstract}

Keywords: Ergonomic conditions; Muscle pain; Thermal comfort 


\section{Introdution}

Ergonomic comfort can directly affect musculoskeletal conditions, reducing productivity and work efficiency. Musculoskeletal symptoms (MS) are a common complaint and involve public spending and absenteeism from work (COLLINS; O’SULLIVAN, 2015).

It is known that MS are a common public health problem, especially in individuals who work with computers. The study of Collins and O'Sullivan (2015) indicated that self-induced MS individuals who work with computers were more frequent in the regions of the neck, shoulder, and lower back and more often noted in women than men.

However, musculoskeletal problems prevail among not only individuals who work with computers, but also university students who are extensive computer users (MARTINS; FELLI, 2013; SOUSA PAIXÃO et al., 2013). With the widespread use of computers by the younger generations, the frequency of these symptoms increased among college students. Coast et al. (2014) found a prevalence of computer-related MS of $80.6 \%$ among female students at a university in USA. Two other studies found prevalence of MS among university students to be 98\% (GOMES et al., 2016) and $100 \%$ (SANCHES et al., 2015).

The major regions of the body affected in students are the neck, upper and lower back, and shoulders (SOUSA PAIXÃO et al., 2013). According to Bruls et al. (2013), the largest number of complaints among the postgraduate students are for the upper extremities, such as the neck and shoulders.

In addition to causing discomfort and pain, MS impairs the academic performance of university students, and cases of students whose academic activities are impaired due to MS are reported (SOUSA PAIXÃO et al., 2013). Mendell et al. (2013) and Lê-Scherban et al. (2014) suggest that inadequate ergonomic conditions can reduce productivity and pleasure in the work or task performed and increase the rates of absenteeism and osteomyoarticular injuries.

Unfavorable environmental conditions, such as high temperatures, excessive noise, inadequate lighting, "a large number of individuals, and inadequate equipment, can reduce performance and cause health problems and absenteeism.

Some professions serve as risk factor for the onset and aggravation of MS. Dentists are generally included among professionals with a higher incidence of musculoskeletal diseases in the course of their professional life (SANCHEZ, 2015). Adoptions of static postures can overload the shoulders and spine, causing orthopedic conditions and overloading of blood vessels (MARTINS FILHO, 2016).

Dentists suffer from low back pain, tension headache, and abnormal exertion in various parts of the spine (thoracic, lumbar, and cervical), upper limbs, and lower limbs, causing various circulatory problems, cervical arthritis, and inflammation of the shoulders, cuticles, and wrists (DE OLIVEIRA; FERREIRA, 2017). There may also be problems, such as degeneration of the intervertebral disc, bursitis, inflammation of the tendon sheath, and arthritis of the hands (SALIBA, 2016).

According to Vuletic et al. (2013), in any of the positions assumed for performing the tasks in dentistry, some inappropriate postures can be observed, for example, torsion in the spine, exaggerated inclination of the neck, left arm constantly raised above $45^{\circ}$ in right-handed professionals, sharp slope forward of the spine, and increased contraction of the muscles of the shoulders and neck.

Therefore, the physical or biomechanical factors associated with the use of force associated with precision, maintenance of static and inadequate postures (especially of the spine and upper limbs), and stress can favor the emergence of disturbances. 
The objective of this study was to evaluate the frequency of MS on the basis of anatomical region, correlate the thermal sensation in the clinical environment with the presence of MS, and investigate factors associated with MS among dentistry students.

\section{Materials and methods}

The present cross-sectional study was conducted at a Higher Education Institution (HEI) in the city of São Luís, Maranhão, Brazil. Initially, this work was approved by the IES Research Ethics Committee. All participants were informed about the objectives and procedures of the study and signed the informed consent form.

Students of both sexes, aged between 19 and 40 years, who were attending the 6th to 10th period of the Graduation Course in Dentistry were included in the study. Those who reported severe and/or congenital musculoskeletal structural diseases were excluded. Thus, the sample size of the present study was 124 .

The characteristics of MS manifestations were evaluated using the Nordic Musculoskeletal Questionnaire (Figure 1), translated into Portuguese and validated by Pinheiro et al. (2002). The instrument assesses complaints of perceived pain in 9 anatomical regions including the neck, shoulders, upper back, elbows, wrist/hand, lower back, hips/thighs, knees, and ankles/feet. The presence of pain complaints (pain, tingling, numbness, discomfort) were investigated in four aspects: 1) occurrence in the last 12 months, 2) impediment to perform daily activities in the last 12 months, 3) search for health services in the last 12 months, and 4) presence of the complaint in the last 7 days. In addition, the participant was asked to classify the pain present in each anatomical region using an ordinal scale (no pain, mild, moderate, and strong).

\section{Figure 1 - Nordic Osteomuscular Symptom Questionnaire with Pain Intensity Scale}

\begin{tabular}{|c|c|c|c|c|c|c|c|c|c|c|c|c|c|}
\hline & & \multicolumn{2}{|c|}{$\begin{array}{l}\text { In the last } 12 \text { months you } \\
\text { have had problems (with } \\
\text { pain, mechanical pain } \\
\text { tingling) in: }\end{array}$} & \multicolumn{2}{|c|}{ 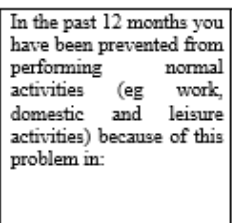 } & \multicolumn{2}{|c|}{$\begin{array}{l}\text { In the last } 12 \text { months, you } \\
\text { have consulted with a } \\
\text { healthcare professional } \\
\text { (physician, } \\
\text { physiothapist) because } \\
\text { of this condition in: cause } \\
\text { of this problem in: }\end{array}$} & \multicolumn{2}{|c|}{$\begin{array}{l}\text { In the last } 7 \text { days, you } \\
\text { have had a problem in: }\end{array}$} & \multicolumn{4}{|c|}{$\begin{array}{l}\text { What is your pain from } 0 \\
\text { to } 3 \text {. Where } 0 \text { is no pain } \\
\text { and } 3 \text { is the worst pain } \\
\text { you have ever felt in life } \\
\text { in } \\
0 \text {-no pain } \\
\text { 1-mild pain } \\
2 \text { - moderate pain } \\
3 \text { - Strong pain }\end{array}$} \\
\hline & Neck & () No & ( )Yes & ( ) No & ()Yes & () No & ( )Yes & () No & () Yes & 0 & 1 & 2 & 3 \\
\hline & Shoulders & () No & ( )Yes & () No & () Yes & () No & ()Yes & () No & () Yes & 0 & 1 & 2 & 3 \\
\hline & Upper back & () No & () Yes & () No & () Yes & () No & () $\mathrm{Yes}_{\mathrm{s}}$ & () No & () $\mathrm{Yes}_{\mathrm{s}}$ & 0 & 1 & 2 & 3 \\
\hline & Elbows & () No & () Yes & ( ) No & () Yes & () No & () Yes & () No & () Yes & 0 & 1 & 2 & 3 \\
\hline & Lower back & () No & ( )Yes & ( ) No & () $\mathrm{Yes}$ & () No & ()Yes & () No & () $\mathrm{Yes}_{\mathrm{es}}$ & 0 & 1 & 2 & 3 \\
\hline & Fists / Hands & () No & () Yes & ( ) No & () $\mathrm{Yes}_{\mathrm{es}}$ & () No & ()Yes & () No & ()Yes & 0 & 1 & 2 & 3 \\
\hline & Hip / Thighs & () No & ()Yes & ( ) No & ()Yes & () No & ()Yes & () No & ()Yes & 0 & 1 & 2 & 3 \\
\hline & Knees & () No & ()Yes & ( ) No & () $\mathrm{Yes}_{\mathrm{s}}$ & () No & ()Yes & () No & () Yes & 0 & 1 & 2 & 3 \\
\hline & Ankles / Feet & () No & ( ) Yes & ( ) No & () Yes & () No & () $\mathrm{Yes}_{\mathrm{es}}$ & () No & () $\mathrm{Yes}_{\mathrm{es}}$ & 0 & 1 & 2 & 3 \\
\hline
\end{tabular}

Thermal comfort was investigated through a self-reported thermal sensation scale in the clinical environment in which the students developed their academic activities at HEI. A seven-point scale was used to classify the thermal sensation: very hot $(+3)$, warm $(+2)$, slightly warm $(+1)$, neutral $(0)$, slightly cold $(-1)$, cold $(-2)$, and very cold $(-3)$, 
according to ISO 10551 (LAMBERTS; PEREIRA, 1997). In addition, variables of the general characteristics, such as sex, age, mean daily sitting time performing academic functions at the dental clinic of the HEI, and medication use for musculoskeletal pain were also added in the questionnaire.

The data were processed using SPSS software version 18.0 (IBM, Chicago, IL, USA). The descriptive statistics were performed by calculating measures of frequency, mean, and standard deviation. The difference in the percentage of reported musculoskeletal pain in the last 12 months by anatomical region among the categorical variables of students' general characteristics was analyzed using the chi-square $\left(\chi^{2}\right)$ or Fisher's exact tests. In addition, the correlation between pain intensity reported between anatomical regions in the last 12 months was estimated by the Spearman correlation coefficient. For all analyses, a significance level of 5\% was adopted.

\section{Results}

A total of 124 students, with mean age of $22.9 \pm 3.9$ years, attending clinical courses between the 6 th and 10 th period of the dentistry course were included in the present study. The general characteristics are presented in Table 1. It was observed that there were more women in the sample (66.1\%). The largest proportion of students remained in activities in the daily academic clinical environment for an average of $4 \mathrm{~h}$ or more $(61.3 \%)$. It was noted that almost $80 \%$ of the students reported attending on average 1 to 2 patients per day. Regarding the perception of thermal sensation in the clinical environment, $33.9 \%$ reported comfortable temperature, followed by slightly warm (26.6\%) and slightly cold $(19.3 \%)$.

Table 1 - Distribution of variables of general characteristics of the sample and thermal sensation in the clinical care environment

\begin{tabular}{|c|c|c|}
\hline Variables & $\mathbf{N}$ & $\%$ \\
\hline \multicolumn{3}{|l|}{ Sex } \\
\hline Female & 82 & $66,1^{*}$ \\
\hline Male & 42 & 33,9 \\
\hline \multicolumn{3}{|l|}{ Age range } \\
\hline 19 to 25 years & 106 & $85,5^{*}$ \\
\hline 26 to 30 years & 13 & 8,9 \\
\hline 31 to 40 years & 5 & 5,6 \\
\hline \multicolumn{3}{|l|}{ Average daily time in clinical care } \\
\hline Until $2 \mathrm{~h}$ & 15 & 12,1 \\
\hline Between 2 and $4 \mathrm{~h}$ & 33 & 26,6 \\
\hline $4 \mathrm{~h}$ or more & 76 & $61,3 *$ \\
\hline \multicolumn{3}{|l|}{ Patients attended per day } \\
\hline 1 to 2 & 99 & 79,9 \\
\hline 3 to 4 & 20 & 16,1 \\
\hline 5 to 6 & 5 & 4,0 \\
\hline \multicolumn{3}{|c|}{ Thermal sensation of clinical environment } \\
\hline Very cold & 0 & 0 \\
\hline Cold & 9 & 7,3 \\
\hline Slightly cold & 24 & 19,3 \\
\hline Neutral (thermal comfort) & 42 & $33,9 *$ \\
\hline Slightly hot & 33 & 26,6 \\
\hline Hot & 14 & 11,3 \\
\hline Very hot & 2 & 1,6 \\
\hline
\end{tabular}


Table 2 presents the distribution of the variables associated with MS by anatomic region. MS experienced in the last 7 days, which may be considered as acute MS, were reported more frequently in the thoracic spinal (20.2\%) and neck (18.5\%) regions For MS in the last 12 months, which can be considered as chronic MS, pain in the thoracic spinal, neck, lumbar spinal, shoulder, and wrist/hand regions was reported in more than $30 \%$ of the students, with MS in the thoracic region being the most frequent at 46\%." The pain in the thoracic spine $(10.5 \%)$ caused the most impediment in performing routine activities in the last 12 months. Pain in the anatomical regions, the neck (8.1\%), followed by the lumbar spine (5.6\%), resulted in the search for professional care. The intensity of MS by region was also investigated, and data showed that severe pain in the last 12 months was more frequent in the lumbar spinal (17.7\%), thoracic spinal (16.9\%), and neck (12.1\%) regions.

Table 2 - Frequencies of musculoskeletal symptoms by anatomical region in the sample of students evaluated

\begin{tabular}{|c|c|c|c|c|c|c|c|c|c|c|}
\hline \multirow{3}{*}{\multicolumn{2}{|c|}{ Questions }} & \multicolumn{9}{|c|}{ Musculoskeletal region valued by the Nordic Musculoskeletal Questionnaire } \\
\hline & & Neck & \begin{tabular}{|c} 
Shoulde \\
rs
\end{tabular} & $\begin{array}{l}\text { Upper } \\
\text { back }\end{array}$ & Elbows & $\begin{array}{l}\text { Fists/ } \\
\text { hand }\end{array}$ & $\begin{array}{c}\text { Lower } \\
\text { back }\end{array}$ & $\begin{array}{l}\text { Hip/ } \\
\text { thighs }\end{array}$ & Knees & $\begin{array}{c}\text { Ankles/ } \\
\text { feet }\end{array}$ \\
\hline & & $\mathrm{n}(\%)$ & $\mathrm{n}(\%)$ & $\mathrm{n}(\%)$ & $\mathrm{n}(\%)$ & $\mathrm{n}(\%)$ & $\mathrm{n}(\%)$ & $\mathrm{n}(\%)$ & $\mathrm{n}(\%)$ & $\mathrm{n}(\%)$ \\
\hline \multirow{2}{*}{\multicolumn{2}{|c|}{$\begin{array}{l}\text { Pain in the } \\
\text { last } 7 \text { days }\end{array}$}} & 23 & 10 & 25 & 3 & 10 & 19 & 5 & 4 & 4 \\
\hline & & $(18,5)$ & $(8,1)$ & $(20,2)$ & $(2,4)$ & $(8,1)$ & $(15,3)$ & $(4,0)$ & $(3,2)$ & $(3,2)$ \\
\hline \multirow{2}{*}{\multicolumn{2}{|c|}{$\begin{array}{l}\text { Pain in the } \\
\text { last } 12 \text { months }\end{array}$}} & 56 & 44 & 57 & 8 & 39 & 51 & 14 & 24 & 23 \\
\hline & & $(45,2)^{*}$ & $(35,5)$ & $(46,0) *$ & $(6,5)$ & $(31,5)$ & $(41,1)$ & $(11,3)$ & $(19,3)$ & $(18,5)$ \\
\hline \multicolumn{2}{|c|}{$\begin{array}{l}\text { Limitations in } \\
\text { activities due to } \\
\text { pain }\end{array}$} & $\begin{array}{c}11 \\
(8,9)\end{array}$ & $\begin{array}{c}5 \\
(4,0)\end{array}$ & $\begin{array}{c}13 \\
(10,5)\end{array}$ & $\begin{array}{c}2 \\
(1,6)\end{array}$ & $\begin{array}{c}6 \\
(4,8)\end{array}$ & $\begin{array}{c}9 \\
(7,3)\end{array}$ & $\begin{array}{c}1 \\
(0,8)\end{array}$ & $\begin{array}{c}3 \\
(2,4)\end{array}$ & $\begin{array}{c}3 \\
(2,4)\end{array}$ \\
\hline \multicolumn{2}{|c|}{$\begin{array}{l}\text { Searched } \\
\text { professional health } \\
\text { care due to pain }\end{array}$} & $\begin{array}{c}10 \\
(8,1)\end{array}$ & $\begin{array}{c}2 \\
(1,6)\end{array}$ & $\begin{array}{c}6 \\
(4,8)\end{array}$ & $\begin{array}{c}2 \\
(1,6)\end{array}$ & $\begin{array}{c}2 \\
(1,6)\end{array}$ & $\begin{array}{c}7 \\
(5,6)\end{array}$ & $\begin{array}{c}2 \\
(1,6)\end{array}$ & $\begin{array}{c}4 \\
(3,2)\end{array}$ & $\begin{array}{c}2 \\
(1,6)\end{array}$ \\
\hline \multirow{4}{*}{$\begin{array}{l}\text { Symptom } \\
\text { severity } \\
\text { in the } \\
\text { last } 12 \\
\text { months }\end{array}$} & $\begin{array}{l}\text { No } \\
\text { pain }\end{array}$ & $\begin{array}{c}68 \\
(54,8)\end{array}$ & $\begin{array}{c}80 \\
(64,5)\end{array}$ & $\begin{array}{c}67 \\
(54,0)\end{array}$ & $\begin{array}{c}116 \\
(93,5)\end{array}$ & $\begin{array}{c}85 \\
(68,5)\end{array}$ & $\begin{array}{c}73 \\
(58,9)\end{array}$ & $\begin{array}{c}110 \\
(88,7)\end{array}$ & $\begin{array}{c}100 \\
(80,6)\end{array}$ & $\begin{array}{c}101 \\
(81,5)\end{array}$ \\
\hline & $\begin{array}{l}\text { Mild } \\
\text { pain }\end{array}$ & $\begin{array}{c}15 \\
(12,1)\end{array}$ & $\begin{array}{c}17 \\
(13,7)\end{array}$ & $\begin{array}{c}23 \\
(18,5)\end{array}$ & $\begin{array}{c}3 \\
(2,4)\end{array}$ & $\begin{array}{c}19 \\
(15,3)\end{array}$ & $\begin{array}{c}12 \\
(9,7)\end{array}$ & $\begin{array}{c}4 \\
(3,2)\end{array}$ & $\begin{array}{c}12 \\
(9,7)\end{array}$ & $\begin{array}{c}8 \\
(6,5)\end{array}$ \\
\hline & $\begin{array}{l}\text { Moderate } \\
\text { pain }\end{array}$ & $\begin{array}{c}26 \\
(21,0)\end{array}$ & $\begin{array}{c}15 \\
(12,1)\end{array}$ & $\begin{array}{c}13 \\
(10,5)\end{array}$ & $\begin{array}{c}3 \\
(2,4)\end{array}$ & $\begin{array}{c}13 \\
(10,5)\end{array}$ & $\begin{array}{c}17 \\
(13,7)\end{array}$ & $\begin{array}{c}5 \\
(4,0)\end{array}$ & $\begin{array}{c}7 \\
(5,6)\end{array}$ & $\begin{array}{c}7 \\
(5,6)\end{array}$ \\
\hline & $\begin{array}{l}\text { Strong } \\
\text { pain }\end{array}$ & $\begin{array}{c}15 \\
(12,1)\end{array}$ & $\begin{array}{c}12 \\
(9,7)\end{array}$ & $\begin{array}{c}21 \\
(16,9)\end{array}$ & $\begin{array}{c}2 \\
(1,6)\end{array}$ & $\begin{array}{c}7 \\
(5,6)\end{array}$ & $\begin{array}{c}22 \\
(17,7)\end{array}$ & $\begin{array}{c}5 \\
(4,0)\end{array}$ & $\begin{array}{c}5 \\
(4,0)\end{array}$ & $\begin{array}{c}8 \\
(6,5)\end{array}$ \\
\hline
\end{tabular}


The MS correlation analysis expressed in Table 3 suggests that the pain intensity reported by the students showed significant proportional correlations with most of the anatomical regions $(\mathrm{P}<0.05)$. It should be noted that the intensity of MS in the thoracic spine and wrist/hand presented a correlation with all other regions. In addition, the strongest correlation measures were between the thoracic and lumbar spine $(\mathrm{Rs}=0.53)$, knee and ankle/foot $(\mathrm{Rs}=0.52)$, and neck and shoulder $(\mathrm{Rs}=0.51)$.

Table 3 - Correlation of the intensity of musculoskeletal pain between anatomical regions

\begin{tabular}{|c|c|c|c|c|c|c|c|c|c|}
\hline \multirow{2}{*}{$\begin{array}{c}\text { Intensity of } \\
\text { pain }\end{array}$} & \multicolumn{9}{|c|}{ Anatomical region } \\
\hline & Neck & Shoulders & $\begin{array}{l}\text { Upper } \\
\text { back }\end{array}$ & Elbows & $\begin{array}{l}\text { Fists/ } \\
\text { hand }\end{array}$ & $\begin{array}{c}\text { Lower } \\
\text { back }\end{array}$ & $\begin{array}{l}\text { Hip/ } \\
\text { thighs }\end{array}$ & Knees & $\begin{array}{c}\text { Ankles } \\
\text { /feet }\end{array}$ \\
\hline Neck & 1 & - & - & - & - & - & - & - & - \\
\hline Shoulder & $\begin{array}{c}0,51 \mathrm{P}< \\
0,001^{*}\end{array}$ & 1 & - & - & - & - & - & - & - \\
\hline Upper back & $\begin{array}{c}0,39 \mathrm{P}< \\
0,001^{*}\end{array}$ & $\begin{array}{c}0,32 \mathrm{P}< \\
0,001^{*}\end{array}$ & 1 & - & - & - & - & - & - \\
\hline Elbows & $\begin{array}{c}0,08 \mathrm{P}= \\
0,343\end{array}$ & $\begin{array}{c}0,31 \mathrm{P}< \\
0,001 *\end{array}$ & $\begin{array}{c}0,21 \mathrm{P}= \\
0,010^{*}\end{array}$ & 1 & - & - & - & - & - \\
\hline $\begin{array}{l}\text { Fists/ } \\
\text { hand }\end{array}$ & $\begin{array}{c}0,23 \mathrm{P} \\
=0,007^{*}\end{array}$ & $\begin{array}{c}0,27 \mathrm{P}= \\
0,001 *\end{array}$ & $\begin{array}{c}0,22 \mathrm{P}= \\
0,012^{*}\end{array}$ & $\begin{array}{c}0,32 \mathrm{P}< \\
0,001 *\end{array}$ & 1 & - & - & - & - \\
\hline $\begin{array}{l}\text { Lower } \\
\text { back }\end{array}$ & $\begin{array}{c}0,34 \mathrm{P}< \\
0,001^{*}\end{array}$ & $\begin{array}{c}0,34 \mathrm{P}< \\
0,001^{*}\end{array}$ & $\begin{array}{c}0,53 \mathrm{P}< \\
0,001 *\end{array}$ & $\begin{array}{c}0,01 \mathrm{P}= \\
0,874\end{array}$ & $\begin{array}{c}0,26 \mathrm{P}= \\
0,002 *\end{array}$ & 1 & - & - & - \\
\hline $\begin{array}{l}\text { Hip/ } \\
\text { thighs }\end{array}$ & $\begin{array}{c}0,25 \mathrm{P}= \\
0,003 *\end{array}$ & $\begin{array}{c}0,25 \mathrm{P}= \\
0,003\end{array}$ & $\begin{array}{c}0,28 \mathrm{P}= \\
0,001 *\end{array}$ & $\begin{array}{c}0,37 \mathrm{P}< \\
0,001 *\end{array}$ & $\begin{array}{c}0,30 \mathrm{P}< \\
0,001^{*}\end{array}$ & $\begin{array}{c}0,35 \mathrm{P}< \\
0,001^{*}\end{array}$ & 1 & - & - \\
\hline Knees & $\begin{array}{c}0,15 \mathrm{P}= \\
0,080\end{array}$ & $\begin{array}{c}0,24 \mathrm{P}= \\
0,006^{*}\end{array}$ & $\begin{array}{c}0,26 \mathrm{P}= \\
0,003^{*}\end{array}$ & $\begin{array}{c}0,36 \mathrm{P}< \\
0,001^{*}\end{array}$ & $\begin{array}{c}0,23 \mathrm{P}= \\
0,008^{*}\end{array}$ & $\begin{array}{c}0,25 \mathrm{P}= \\
0,003^{*}\end{array}$ & $\begin{array}{l}0,43 \mathrm{P}< \\
0,001 *\end{array}$ & 1 & - \\
\hline $\begin{array}{l}\text { Ankles/ } \\
\text { feet }\end{array}$ & $\begin{array}{c}0,15 \mathrm{P}= \\
0,083\end{array}$ & $\begin{array}{c}0,26 \mathrm{P}= \\
0,003^{*}\end{array}$ & $\begin{array}{c}0,20 \mathrm{P}= \\
0,019^{*}\end{array}$ & $\begin{array}{c}0,27 \mathrm{P}= \\
0,001^{*}\end{array}$ & $\begin{array}{c}0,21 \mathrm{P}= \\
0,014^{*}\end{array}$ & $\begin{array}{c}0,13 \mathrm{P}= \\
0,150\end{array}$ & $\begin{array}{c}0,46 \mathrm{P}< \\
0,001^{*}\end{array}$ & $\begin{array}{c}0,52 \mathrm{P}< \\
0,001^{*}\end{array}$ & 1 \\
\hline
\end{tabular}

*Statistically significant correlation $(\mathrm{P}<0.05)$

Table 4 shows the variables associated with the presence of MS by anatomic region. Data reveal that women presented a significantly higher frequency of MS in the neck $(\mathrm{P}=0.01)$, shoulder $(\mathrm{P}=0.01)$, and lumbar spine $(\mathrm{P}=0.01)$. Neck pain seems to be associated with thermal discomfort, since it was more frequent in students who reported feeling cold in the academic clinical environment $(\mathrm{P}=0.02)$. Pain in the thoracic spine had higher frequency among students who remained in clinical care for an average of $4 \mathrm{~h}$ or more per day $(\mathrm{P}=$ 0.01). In addition, the use of analgesics was more frequent in students who reported $\mathrm{MS}$ in the lumbar spine $(\mathrm{P}=$ $0.03)$ and ankle/foot $(\mathrm{P}=0.03)$. The age group and number of patients attended were not associated with MS in the sample of students evaluated. 


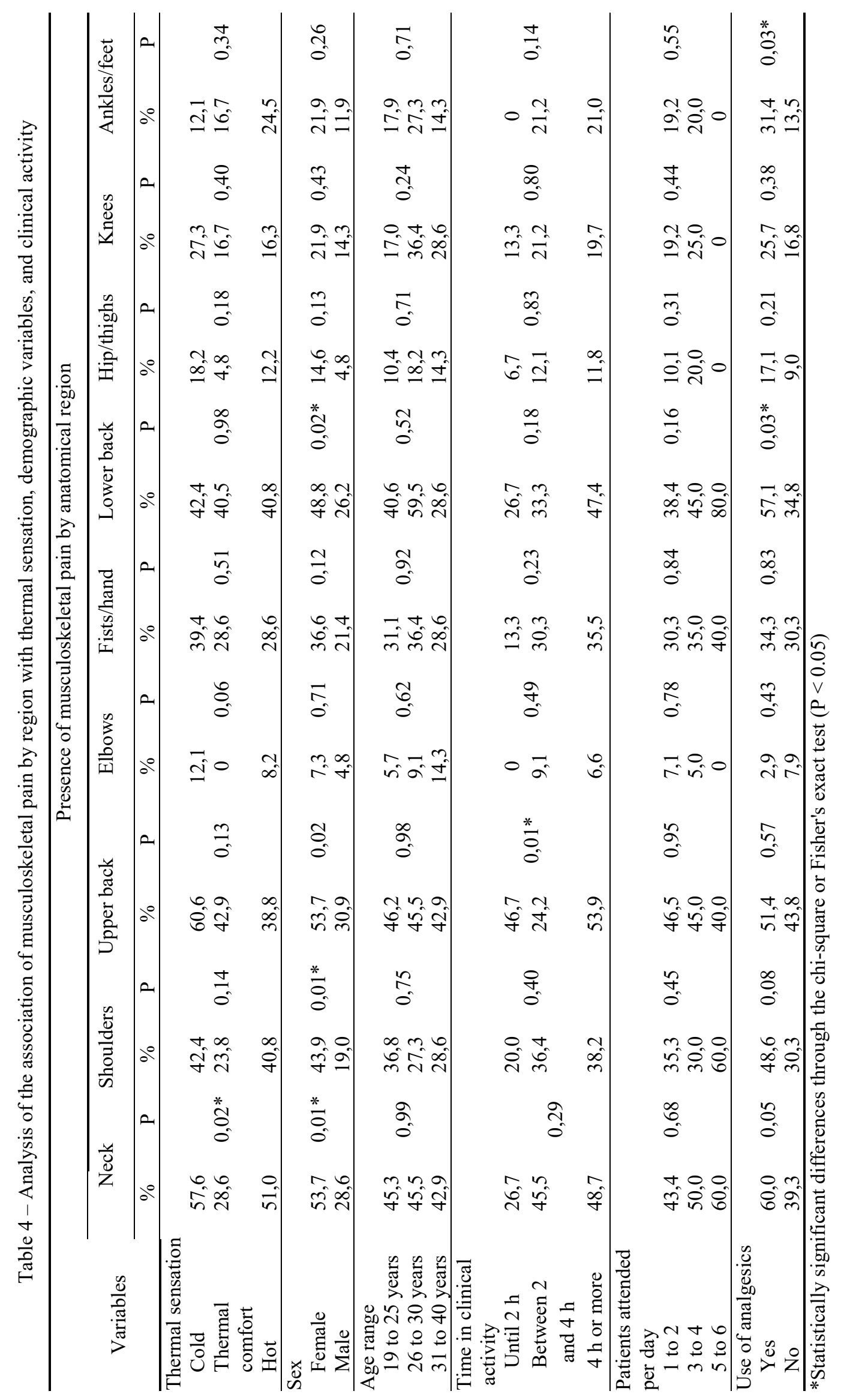




\section{Discussion}

About half the world's population invests a third of their lives at work, and nearly $40 \%$ of the employees face significant occupational hazards. In dentistry, as in other professions, there are several factors that expose these health professionals to high risks if they do not conform to occupational health standards (AGHAHI et al., 2018).

Studies have shown that dentists are exposed to the risk of musculoskeletal problems more than any other medical professional. Therefore, the recognition of ergonomic factors in the workplace of these professionals is very important; additionally, dentistry is a profession that requires continuous care. The tools, technology, and technical skills used by dentists have a significant impact on the health of the professionals and of their patients (AGHAHI et al., 2018). The musculoskeletal symptoms, both acute and chronic, were highly frequent in the students of dentistry, primarily in the spine as a whole, followed by the shoulders and the wrist/hand. A previous study revealed that due to lack of experience, the lower the academic level, the greater is the risk of developing occupational diseases (ROVIDA et al., 2015), possibly due to lack of attention and knowledge of the importance of ergonomic position during work activities; this can be proven by our study, because, when the students were questioned on MS based on the anatomical regions, we noticed a greater experience of pain in the lumbar spine in the last 12 months, followed by the thoracic spine and neck. The discomfort in these regions may be directly related to the postures adopted during the school stage activities and long periods of maintaining this posture (MOYAHHED et al., 2013).

The prevalence of MS in dental academicians can be explained by the posture adopted, coinciding with the results reported in the study by Decharat et al. (2016), where, as in our data, the region most commonly affected by pain was the thoracic spine, followed by neck and lower back. Although the prevalence of MS has been high, the percentage of individuals seeking professional help to treat these symptoms is relatively low, and individuals with complaints in the thoracic region most commonly seek professional help, possibly because pain is considered mild or moderate by the majority of the respondents.

The positive correlation observed between the intensity of MS in the thoracic spine and wrist/hand and all other regions draws attention to the interdependence of symptoms, and the presence of MS in the thoracic spine may be a predisposing or even worsening factor for the symptoms of other regions. The findings of this study indicate that most students accomplish their clinical practice while experiencing pain in the spine and upper limbs, which is associated with not only academic activity, but also other external factors, such as daily habits and attitudes unrelated to clinic practice. Westgard et al. (1999) and Lehto et al. (1991) reported that the presence of these disorders may be associated with multiple clinical factors, such as static postures, poor lighting, poor posture, time in practice, and insufficient time for rest.

The lack of adequate planning of the environment and work equipment favors the development of disorders in the osteomuscular system. Hayes et al. (2014), Khan et al. (2014), and Movahhed et al. (2016) in previous studies revealed that the neck, shoulder, and upper and lower back regions are more susceptible to injury, since most students elevate the head, flex the neck, and rotate the shoulder and spine to an unstable position and without symmetrical support for better vision and access.

Posture is related to body consciousness, which is a form of self-knowledge, that is, understanding of what the body is capable of doing, as well as its limitations. Diseases can arise over the years by pushing the body beyond what it is able to withstand, and knowing and respecting the bodily limits can prevent illness. 
Collins and O'Sullivan (2015) reported that body awareness awakens internal strategies for combating illness and developing postures and attitudes that improve the quality of life and even interpersonal relationships.

The ergonomic factors to be considered can be summarized as upper limb supports, use of instruments with large lugs, and working with a mechanically adjustable backrest, accent, and armchair. The use of indirect vision and correct positioning of the patient in the dental chair to avoid inappropriate or forced neck postures are also important. Proper lighting and the use of systems, such as magnifying glasses and microscopes, as well as the appropriate temperature also aid in reducing fatigue and increase productivity (VERHAGEN et al., 2004).

However, only the improvement in the ergonomics of dental equipment has not been sufficient to reduce the incidence of musculoskeletal disorders (SOUSA; MAZINI FILHOS, 2017) since the etiology of musculoskeletal disease is multifactorial and involves biomechanical, individual, and psychosocial factors. Consequently, the preventive strategy should be multifactorial and not only focused on ergonomics (BIZELLI, 2015). Prevention strategies should focus on the following areas: ergonomics, work breaks, general health, and exercise (VALACHI; VALACHI, 2003).

The majority of the students considered the environment to be thermally neutral, that is, they felt comfortable with the temperature; if the number of students who considered the environmental conditions to be uncomfortable is considered, then it can be concluded that the temperature of the environment was not comfortable for the majority of the students. In addition, thermal sensation was associated with MS of the neck region, possibly because it remained exposed during the visits, allowing a greater occurrence of pain. To the best of our knowledge, this is the first work to point to this association.

An association was found between the female sex and MS in the neck, shoulders, and lumbar spine. This association has previously been observed and seems to be related to greater musculoskeletal frailty, lower tonus, and higher incidence of osteoporosis in women (LEHTO et al, 1990). Moreover, an association was observed between the longer treatment and symptoms in the thoracic region and the use of analgesics and pain in the lumbar or ankle/foot, possibly because these were indicated as regions with severe pain. This work adds up to other studies pointing out that repetitive movements and prolonged body postures can cause muscle damage, as well as ligaments and joint injuries (DE OLIVEIRA; FERREIRA, 2017; ROVIDA et al., 2015; MANSFIELD et al., 2018) for the urgency of the prevention of MS in dentistry students.

\section{Conclusions}

MS are common among dentistry students, especially in women, which is associated with symptoms in the regions of the neck, shoulder, and lumbar spine. The region of the spine (neck and thoracic and lumbar spine) is the most affected area in both sexes, although the symptoms are not intense enough to lead the search for specialized professionals, and pain in the neck region is correlated with thermal cold sensation.

Prospective studies that encourage prevention through not only ergonomic changes but also general lifestyle habits are needed to stimulate prevention and reduce the high frequencies of pain in dentistry students.

\section{Acknowledgments}

We thank the staff and students of the School Clinic of the Ceuma University for their help and participation in this work and the Foundation for Research and Scientific and Technological Development of Maranhão FAPEMA. 


\section{References}

BIZELLI, G.R et al. Ginástica laboral como forma de prevenção das desordens musculoesqueléticas no aluno de odontologia. In: Congresso de extensão universitária da UNESP. Universidade Estadual Paulista (UNESP), 2015. p. 1-5.

Bruls, V.E.; Bastiaenen, C.H.; de Bie, R.A. [Non-traumatic arm, neck and shoulder complaints: Prevalence, course and prognosis in a Dutch university population]. BMC Musculoskelet. Disord. 2013,4;14:8.

COLLINS, JD.; O'SULLIVAN, LW. [Musculoskeletal disorder prevalence and psychosocialrisk exposures by age and gender in a cohort of office based employees in two academic institutions]. Int. J. Ind. Ergon. 2015,46, 85-97.

DA COSTA, A.M et al. Prevalência de sintomas musculoesqueléticos em profissionais de uma instituição de ensino superior. Espaço para Saúde, v. 14, n. 1/2, p. 41-50, 2014.

DE OLIVEIRA, L.Q.; FERREIRA, M.B.C. [Ergonomics in dental pratice]. Journal of Oral Investigations, 2017, $6,1,15-28$.

DE SOUSA PAIXÃO, M; MIRANDA TASSITANO, R; SIQUEIRA, G.R. Prevalência de desconforto osteomuscular e fatores associados em estudantes universitários. Revista Brasileira em Promoção da Saúde, 2013,26(2), 242-250.

DECHARAT S.; PHETHUAYLUK P.; MANEELOK S. [Prevalence of Musculoskeletal Symptoms among Dental Health Workers, Southern Thailand]. Advances in Preventive Medicine. 2016.1, 1-6.

GOMES-NETO, M.; SAMPAIO, G.S.; SANTOS, P.S. Frequência e fatores associados a dores musculoesqueléticas em estudantes universitários. Revista Pesquisa em Fisioterapia, 2016,6 (1), 26-34.

HAYES, M. J. et al. [The effect of wearing loupes on upper extremity musculoskeletal disorders among dental hygienists]. International journal of dental hygiene, 2014,12,174-179.

KHAN, SA; CHEW, KY; 2013. [Effect of working characteristics and taught ergonomics on the prevalence of musculoskeletal disorders amongst dental students]. BMC Musculoskeletal Disorders. 2013,14, 118-125.

LAMBERTS, R; DUTRA, L; PEREIRA, F.O.R. Eficiência energética na arquitetura. Universidade Federal de Santa Catarina, Florianópolis. 1997.

LEHTO TU, HELENIUS HY, ALARANTA HT. [Musculoskeletal symptoms of dentists assessed by a multidisciplinary approach]. Community Dent Oral Epidemiol 1991; 19:38-44.

LEHTO TU, RÖNNEMAA TE, AALTO TV, HELENIUS HY. [Roentgenological arthrosis of the hand in dentists with reference to manual function]. Community Dent Oral Epidemiol. 1990; 18:37-41.

LÊ-SCHERBAN, F et al. [Does academic achievement during childhood and adolescence benefit later health?. Annals of epidemiology]. 2014,24(5): 344-355.

MANSFIELD, M.; THACKER, M.S.T. [Physical activity participation and the association with work-related upper quadrant disorders (WRUQDs)]: A systematic review. Musculoskeletal care, 2018,16 (1): 178-187.

MARTINS FILHO, Ismar Eduardo et al. Prevalência de sintomas osteomusculares em estudantes de odontologia e docentes da Universidade Estadual do Sudoeste da Bahia, Campus Jequié. Saúde Rev. Saúde. 2016; 12(1): 477-481.

MARTINS, Aline Caldas; FELLI, Vanda Elisa Andres. Sintomas musculoesqueléticos em graduandos de enfermagem. Enfermagem em Foco, 2013,4(1):58-62. 
MENDELL, MJ; ELISEEVA, EA; DAVIES, MM; SPEARS, M; LOBSCHEID, A, FISK, WJ. ET AL. [Association of classroom ventilation with reduced illness absence: a prospective study in California elementary schools]. Indoor Air J. 2013,65, 15-28.

MOVAHHED, T; AJAMI, B; SOLTANI, M; SHAKERI, MT; DEHGHANI, M; 2013. [Musculoskeletal pain reports among Mashhad dental students]. Pak J Biol Sci. 2016 (2), 80 - 5.

PINHEIRO, FA, et al. Validação do Questionário Nórdico de Sintomas Osteomusculares como medida de morbidade. Rev. Saúde Pública. 2002,36(3), 307-12.

Rovida, T.A.S et al. Ergonomia odontológica: integrando teoria e prática para o avanço do ensino. Revista da ABENO. 2015,15(4), $37-44$.

SALIBA, T.A. et al. Distúrbios osteomusculares em cirurgiões-dentistas e qualidade de vida. Rev. Dor. 2016,17(4): 261-265.

SANCHEZ HM, et al. Dor musculoesquelética em estudantes de odontologia. Rev Bras Med Trab. 2015; 13(1):23-30.

SOUZA, Josiane Aparecida Cardoso de; MAZINI FILHO, Mauro Lúcio. [Ergonomics posture and movement analyses of supermarket checkout operators in the city of Cataguases]. Gest. Prod., São Carlos. 2017,24(1): 123135.

VALACHI, B.; VALACHI, K. Preventing musculoskeletal disorders in clinical dentistry: strategies to address the mechanisms leading to musculoskeletal disorders. J Am Dent Assoc. 2003;134:1604-12.

VERHAGEN, A.P.; BIERMA-ZEINSTRA, S.M.; FELEUS, A.; KARELS, C.; DAHAGHIN, S.; BURDORF, L.; et. al. [Ergonomic and physiotherapeutic interventions for treating upper extremity work related disorders in adults]. Cochrane Database Syst Rev. 2004;1:CD003471.

VULETIĆ, J. et al. Prevalence and risk factors for musculoskeletal disorders in dentists. Stomatoloski glasnik Srbije, v. 60, n. 1, p. 24-31, 2013.

WESTGAARD RH. [Effects of physical and mental stressors on muscle pain]. Scand J Work Environ Health 1999; 25:19-24. 